\title{
Milton's Portrayal of Satan in Paradise Lost and the Notion of Heroism
}

\author{
Jamal Subhi Ismail Nafi' \\ Department of English, Al-Quds University, East Jerusalem-Abu Dies Main Campus, Palestine
}

Email address:

jamalnafi@gmail.com,nafi@arts.alquds.edu

To cite this article:

Jamal Subhi Ismail Nafi'. Milton's Portrayal of Satan in Paradise Lost and the Notion of Heroism. International Journal of Literature and Arts. Vol. 3, No. 3, 2015, pp. 22-28. doi: 10.11648/j.ijla.20150303.11

\begin{abstract}
This paper examines the question whether Satan is really the hero of John Milton's great epic poem Paradise Lost (1667). There are controversial debates over this issue, and most critics believe that, although Satan acts and speaks heroically, God is the real hero of the poem, not Satan. The paper adopts the analytical approach. The findings of the paper reveal that the central character Satan is a devil that acts for his own self-interests, and cannot do good, even to his followers, the fallen angels. The paper finally shows that, every impulse in Satan towards good has died out. The element of nobility that redeemed his character at the outset from absolute baseness has been killed. Hardly therefore shall we believe that Milton meant us to see in the fallen and ever falling archangel the hero of his poem. That position surely belongs to Adam.
\end{abstract}

Keywords: Deterioration, Devil, Heaven, Hell, Heroism, Milton, Paradise Lost, Punishment, Satan, Theology

\section{Introduction}

The view has been expressed that Satan is the real hero of John Milton's great epic poem Paradise Lost, or that Milton permitted Satan to develop into a character far more appealing than Milton's theology could have allowed. In the words of Banisalamah (2015), people of the seventeenth century were encouraged to and inspired by the revolutionary writings of Milton, who was a Puritan poet, to seek freedom from the king and the Roman Catholic Church, in order to improve their conditions and live a more pleasant life, and this is represented by Satan's revolt against God, a revolt which makes him appear as if he were a hero in the eyes of some critics and readers. This view originated during the Romantic age, with its rebellion against all established forms of authority and its emphasis on the development of personality (whether in the author or in one of his characters). According to Gordon (2005), it was Blake who expressed this view most emphatically by saying that Milton was of the devil's party without knowing it. He expressed this opinion chiefly in relation to the portrayal of Satan who, according to him, has been depicted as a character possessing certain grand qualities worthy of the highest admiration. Other romantic critics supported this view with great enthusiasm. Shelley (1998), for instance, reinforced this view when, in his "Defense of Poetry," he said:
"Nothing can exceed the energy and magnificence of the character of Satan as expressed in Paradise Lost. It is a mistake to suppose that he could ever have been intended for the popular personification of evil. Milton's Devil as a moral being is as far superior to God, as one who perseveres in some purpose which he has conceived to be excellent in spite of adversity and torture, is to one who in the cold security of undoubted triumph inflicts the most horrible revenge upon his enemy." (12).

According to Shelly (Ibid), it was a mistake to think that Satan was intended by Milton as the popular personification of evil. This argument is still very much alive and valid today.

But the most eloquent and balanced expression of the Romantic view has been given by William Hazlitt. Hazlitt (1818) shows both the strength and the limitations of this view, and according to him, Satan is the most heroic subject that was ever chosen for a poem; and the execution is as perfect as the design is lofty. In the poem, Satan was endowed with certain attributes which are worthy of epic heroes, and which make him a sympathetic, almost tragic character.

\section{Discussion}

The very descriptions of Satan's physical dimensions and the size of the tools he carries mark him out as a kind of hero. His limbs are long and large; his bulk is as huge as that of the 
Titan who fought against Jove or that of Leviathan which God of all His works created hugest that swim the ocean stream. He has a mighty stature so that, when he rises, the flames on both sides of him are driven backward and roll in billows. He carries a ponderous, massy, and large shield on his shoulder. This shield is compared to the moon as seen through a telescope. His spear is so big that the tallest pine tree would be but a wand by comparison, etc. This description may be valid if we consider the epic as showing Satan as a character who "materializes hope, basing his hopes to gain power on the acquisition of land" (Fenton, 2003: n.p.).Combined to these great qualities, Satan was the first of created beings who, for endeavoring to be equal with the highest and to divide the empire of Heaven with the Almighty, was hurled down to Hell. His aim was no less than the throne of the universe. His ambition was the greatest, and his punishment was the greatest, but not so his despair, for his fortitude was as great as his sufferings. Slotkin (2004, as cited in Smilie, 2013) is also of the view that "God's punishments turn their victims into allegories of their own crimes" (114), a notion confirmed by Satan's famous assertion "Myself am Hell" (IV. 75). His strength of mind was matchless as his strength of body. His power of action and of suffering was equal. He was the greatest power that was ever overthrown, with the strongest will left to resist or to endure. He was baffled, not confounded. He still stood like a tower, proudly eminent in shape and gesture. An outcast from Heaven, Hell trembles beneath his feet; Sin and Death are at his heels, and mankind are his easy prey. Milton's has rightly said in Book I:

All is not lost; the unconquerable will,

And study of revenge, immortal hate,

And courage never to submit or yield,

And what else is not to be overcome. (106-109).

The above words indicate that the sense of Satan's punishment seems lost in the magnitude of it; the loss of infinite happiness to himself is compensated in thought, by the power of inflicting infinite misery on others. Yet Satan is not the principle of malignity, or of the abstract love of evil, but of the abstract love of power, or pride, of self-will personified. His love of power and contempt for suffering is never once relaxed from the highest pitch of intensity (...) After such a conflict as his, and such a defeat, to retreat in order to rally, to make terms, to exist at all, is something; but he does more than this-he found a new empire in Hell, and from it conquers this new world, wither he bends his undaunted flight. The poet has not in all this given us a mere shadowy outline; the strength is equal to the magnitude of the conception.

Wherever the figure of Satan is introduced, whether he walks or flies, it is illustrated with the most striking and appropriate images: so that we see it always before us, gigantic, irregular, portentous, uneasy, and disturbed- but dazzling in its faded splendor, the clouded ruins of a god. The deformity of Satan is only in the depravity of his will; he has no bodily deformity to excite our loathing or disgust. Milton was too magnanimous and opens an antagonist to support his argument by the bye-tricks of a hump and cloven feet. He relied on the justice of his cause, and did not scruple to give the devil his due. Some persons may think that he has carried his liberality too far, and injured the cause he professed to espouse by making him the chief person in his poem. Considering the nature of his subject, he would be equally in danger of running into this fault, from his faith in religion, and his love of rebellion; and perhaps each of these motives had its full share in determining the choice of his subject.

The Romantic view has persisted since Blake and Shelley emphatically expressed it. The argument is, in brief, that, since God is so unpleasant and Satan is a being of such magnificent vitality. According to Prince (1962), Milton must have "put his heart and soul into the projection of Satan" in spite of his consciously different purpose (3). Virgil's epic poem The Aeneid offers a partial parallel. In the ancient epic the nominal hero seems to be greatly overshadowed by a character with whom we were not intended to sympathize. For many readers, Virgil's most vital and central figure is Dido. She alone is humanly and tragically real, while Aeneas, the embodiment of Roman virtue, and Jupiter are, like Milton's Adam and God, pallid, self-righteous, and irritating. To persons of this way of thinking, there seems to be a central discord in both poems, a conflict between the poet's intention and the result. Both Dido and Satan, it appears, are much too great and attractive for their functional role as villains. It would seem, therefore, that Virgil, and Milton wanted to set forth certain orthodox principles but were carried away unconsciously by their hearts and imaginations (Williamson, 1965). No doubt, artists have sometimes produced effects different from what they intended. But both Virgil and Milton have clearly given us the impression of knowing what they were about. It would for this reason be impossible to believe that these poets should in their major works reveal a fundamental religious and moral contradiction.

Those who glorify Satan regard Milton's God as an almighty King Charles, a tyrant against whom it was glorious to rebel. In King's (2000) opinion, this is a wild notion in view of the fact that "Milton conceived of God as the supreme source and symbol of love, mercy, justice, reason, and order" (18). The fact is simply that the modern world has moved quite away from the old assumptions and doctrines of religious, ethical, social, and cosmic order and right reason. Among the general reading public, three out of four persons instinctively sympathize with any character who suffers and rebels, and pay little heed to the moral values and responsibilities involved, because in such cases, the sinner is always right, and authority and rectitude are always wrong. This instinctive response has grown the stronger as religion and morality have been increasingly undermined by romantic naturalism and sentimentalism.

The common fallacy begins with a basic misunderstanding of the beginning of Paradise Lost, namely, Satan's first speech delivered as he surveys his followers rolling in the fiery gulf, confounded through immortal. "Our response to this speech is prepared for through the picture of the 
archangel torn by wholly evil passions" claimed Murray (1967: 50). But even if there were no such preparation, the speech itself in every line should arouse horror and repulsion. It is a dramatic revelation of nothing but egoistic pride and passion, of complete spiritual blindness. The "potent victor in his rage" is blind and blasphemous description of God. Nothing that the "victor" can inflict will make Satan "repent or change." This phrase is a rejection of all Christian teaching Satan's "injured merit" is a figment of his own egoism, quite the opposite of the real and selfless merit of Christ. "What though the field be lost? / All is not lost..." (I. 99). These famous lines embody, not the spirit of the Puritan armies, but the spirit of Hitler. Satan sees only a conflict between himself the world conqueror, and a temporarily superior force; he cannot see that it is a conflict between evil and good. "The unconquerable will" is not the religious and naturalistic will to power. "Sturdy of revenge" and "immortal hate" brand themselves. "Courage never to submit or yield" is not true courage; it is the courage of a wolf at bay; it is desperate perseverance in evil. In short, if we think that defiance is splendid regardless of what is defied and, if we read this speech with a thrill of sympathy in reading the speeches of such Shakespearean villains as Iago, Edmund, and Macbeth. According to King (2000), even Walter Landor, a romantic revolutionary, could say: "There is neither truth nor wit is saying that Satan is the hero of the piece unless, as is usually the case in human life, he is the greatest hero who gives the wildest sway to the worst passions" (20).

There is no conflict here (in this first speech of Satan) between Milton's intention and the result, and there is none later, even when Milton leaves dramatic speech to create its own effect. Those who admire the rebel of the first speech also admire him when he declares:

... Here at least

We shall be free...

To reign is worth ambition though in hell:

Better to reign in Hell, than serve in Heaven. (I. 258-263)

But to those who understand and realize Milton's principles, which are everywhere made clear, such words show how far Satan is from understanding true liberty. The tyrant of Milton's poem, as some have seen, is not God but Satan.

Of course, Satan has heroic qualities. He is brave, strong, generous, loyal, prudent, temperate, and self-sacrificing. And if Satan has heroic virtues, so has Macbeth; both characters possess the emotional advantage of fighting against odds, while the representatives of goodness and right have irresistible power (Williamson, 1965). The situation in fact is essentially the same. Satan is overthrown when Christ is armed with the might of God; Macbeth, who has leagued himself with the powers of Satan, is overthrown by the English army which is, says Malcolm, the instrument of the powers above. Both poets, though imaginatively capable of creating a great villain, are constrained by their traditional faith in Providence and the ultimate triumph of good to bring divine power to the defeat of evil and, compared with the dauntless archangel and the bloody tyrant at bay, Christ and Malcolm may not win much of our sympathy. In a critical essay, Anderson (2010) states that, for the purpose of allowing readers to uphold or reject divine law, Milton includes elements in the poem contrary to the will of God. These elements add to the paradoxical nature of Satan's portrayal, and "these conflicting aims ultimately lend contrary thematic values to the poem" (198).

It has been the practice of all epic poets to select someone personage, whom they distinguish above all the rest, and make the hero of the tale. This is considered essential to epic composition, and is attended with several advantages. It renders the unity of the subject more sensible, when there is one principal figure, to which as to a center, all the rest refer. In the words of Fuller (1944), "it tends to interest us more in which enterprise which is carried on; and it gives the poet an opportunity of exerting his talents for adorning and displaying one character with peculiar splendor" (15). It has been asked, who then is the hero of Paradise Lost? The Devil, it has been answered by some critics; and, in consequence of this idea, "much ridicule and censure have been thrown upon Milton" (Rudrun, 1966: 25). But they have mistaken that author's intention, by proceeding upon a supposition that, in the conclusion of the poem, the hero must need be triumphant, whereas Milton followed a different plan and has given a tragic conclusion to a poem otherwise epic in its form. For Adam is undoubtedly his hero; that is, the capital and most interesting figure in his poem.

The figure of Satan has always fascinated readers of Paradise Lost. Some have claimed him as the secret hero of the story. But that is a misunderstanding. An adversary of God had to be massive dramatic stature, and it was a triumph that Milton succeeded in drawing him to such a scale. The misinterpretation springs from the tendency in human nature to romanticize the rebel and the fighter against odds. To understand Satan we must not lose sight of the treachery of his rebellion, or against whom it was directed, and how his frustrated rage expresses itself in a cruel effort to destroy creatures that have not harmed him. His speeches are impressively high-sounding but when examined they prove to be boasts and lies (Broadbent, 1972). Milton has exposed all those false romantic notions of heroism as egotistical magnificence, the idea that heroic energy in a bad cause is admirable.

As stated by Dunbar (1980), Blake made the following observation regarding Paradise Lost: "The reason Milton wrote in fetters when he wrote of angels and at liberty when of devils and Hell, is because he was a true poet and of the devil's party without knowing it" (16). In Blake's opinion, Satan was a symbol of desire, energy, and the vital creative force which enable man to live most fully. God represented old, life-denying reason and passivity which are only the shadow of desire. Certainly the conventional Heaven and rationalizing God of Paradise Lost are pale and unconvincing when compared to the descriptions of Hell and the tremendous energy and courage of Satan. Satan has been imagined and described in this poem with a wealth of vivid 
detail which no other character in it can equal. Satan is, by any standards, a character of epic stature.

The reason why Satan is so fully imagined and so fascinating is partly that Milton felt inspired by him and partly that it is always much easier to create evil people that ideally good ones. (Adam is a "mixed" character because though created good, he falls, but though mixed, he too has been imagined with the greatest sensitivity and fullness). Milton wanted to show that evil fascinated our first parents. Eve fell when Satan made disobedience seen attractive to her. Evil can be interesting, can inspire us, and can even have its own perverse beauty. Milton strongly condemned evil but he could yet show it at work in Satan's temptations, and he found a splendid symbol for it in Pandemonium.

In Books I and II of Paradise Lost, Satan is depicted as heroic, but his is false heroism as it is based on false beliefs and unworthy aims and aspirations. It was Shawcross (1972) who considered Satan's heroism as "false heroism that has its dramatic side and a certain interest" (34). Satan may be perverse, but his desire for revenge gives him energy, and his energy makes him exciting and interesting. He has all the attributes of an epic hero and all the attraction. At the beginning of the poem he is placed in a dramatic situation. His reactions to this situation have a thrilling effect on us. His speeches are full of stirring, highly emotive words such as "liberty," "oppression," and "freedom." It was partly their deep love of liberty that caused the Romantics like Blake and Shelley to respond so warmly to the character of Satan. Satan is markedly like a romantic hero (such as the characters in Byron's Oriental tales). But Milton was not a romantic poet, and his treatment of Satan shows the weaknesses of the romantic position. Milton relentlessly exposes the willful, self-centered revengefulness of Satan, though on the surface this attitude of Satan looks like heroism.

Satan, as portrayed by Milton, was a new kind of character in epic poetry. In medieval and Renaissance literature, the devil was usually presented in a monstrous form. Tasso, for example, depicted Satan with blood-shot eyes, blooddripping jaws, a mouth as high as a whirlpool. A devil of this kind is grotesque, and is intended to frighten the reader. Such a devil cannot convey to the reader the nature of $\sin$ or temptation. Sin and temptation are parts of human or almost human form. Milton's devil is superhuman, but he also shows the full range of human characteristics. In depicting him, Milton departed from the crude tradition of earlier religious epics and seems to have adopted ideas from the Elizabethan and Jacobean stage. As has been stated by Daiches (1976), most of the villains in the Elizabethan and Jacobean drama have enough human characteristics to save them from becoming mere monsters. Milton too humanizes his Satan. Satan's character has depth. It shows changes of mood: the fluctuations of revengefulness, pride, and despair. It is realistic and near-heroic, whereas earlier devils were merely monsters.

Satan is proud, of course. But beneath this pride lies a tormenting sense of despair. This despair overwhelms him until at last only the desire for revenge reigns supreme in his nature. In Book IV, he experiences "troubled thoughts" for:

\section{Within him Hell}

He brings, and round about him, nor from Hell

One step, no more than from himself, can fly

By change of place. Now conscience wakes despair

That slumbered; wakes the bitter memory

Of what he was, what is, and what must be. (20-25).

Satan embodies the powerful idea that Marlowe's devil Mephistopheles expresses when he speaks to Faustus in the latter's study: "Myself am Hell, nor am I out of it." Tillyard (1938) commented on this by saying that Satan's words regarding the change of place, which will never change his mind, suggest his heroic stature and a mind that will not relent, but will follow the plan of revenge till the end, no matter what the results are.

Satan's outward appearance shows his spiritual decline. In Book IV he has degenerated to such an extent that, when he is discovered tempting Eve, his former companion in Heaven, Gabriel, does not immediately recognize him. In Book XI he returns to Hell after successfully destroying the innocence of Adam and Eve, and is turned into the serpent whose form he had adopted when concealed in Paradise. The passages describing Satan's appearance are like a chart indicating his moral decline from the imaginative picture of an "Archangel ruined" which exactly describes him at first. These passages emphasize the reality behind Satan's evasions and pretence. They increase our awareness of the hollowness of Satan's heroic postures. They also keep before our eyes the deceptiveness which is a great part of the experience and pleasure of sin.

The first two books of Paradise Lost show that Satan mainly as seen through his eyes. Milton's brief comments on Satan seem out of tune with the stirring quality of Satan's speeches. These comments seem harsh and unsympathetic but they serve to remind us of the extent to which we are being carried away by Satan's glamour and rhetoric. We are struck by the splendors of the heroic setting and we are made to experience the pleasurable excitement of coming into contact with sin. In both books I and II we almost forget the distinction between goodness and self-centered energy. Satan makes high-sounding speeches. He dramatizes his situation. He makes himself an epic hero. He deceives his followers by thrilling their imaginations. But, if we analyze his speeches, we find that there are several evasions on Satan's part and that he makes certain assertions which are unsupported by evidence.

A passage from Book I will serve as an illustration of what has been said above. In his first speech to Beelzebub, Satan gives us an account of the reasons for their failure to win the war in Heaven. In the main part of the speech (Lines 94-124), Satan makes a series of high-sounding assertions and rhetorical gestures. But these assertions have no real basis according to Lewis (2005). He speaks of his "fixed mind" and "high disdain from sense of injured merit" which made him rebellious when God placed the Son in the position which Satan believed should have been assigned to him. This 
is merely an expression of jealousy, selfishness, and failure to love God. In describing his rebellion he represents God as a tyrannical overlord:

\section{And to the fierce contention brought along Innumerable force of Spirits armed, That durst dislike his reign, and, me preferring, His utmost power with adverse power opposed In dubious battle on the plains of Heaven, And shook his throne. (I. 100-105).}

These words show not only manipulations of the truth but also self-deception. Book VI makes clear that the battle was never dubious. The idea of God's throne being shaken shows merely wishful thinking. The lines that follow betray further unsupported assertions:

All is lost-the unconquerable will,

And study of revenge, immortal hate,

And courage never to submit or yield,

And what is else not to be overcome?

That glory never shall his wrath or might

Extort from me. (I. 106-111)

Milton here exposes the emptiness of heroic postures. The word "glory" used by Satan is, for example, utterly meaningless. For God to exact obedience from his own servant could hardly be any significant triumph. Satan's language would be appropriate only if the struggle had been between equals. His manipulations and abuses of language in Paradise Lost threaten can be viewed, as an attempt on Satan's part to "take over the power of God's words" (Forsyth, 2003, as cited in Morrison, 2009. 175), and that he challenges God for control and dominance of the serpent image.

There is in Milton's Satan a unique combination of epic grandeur and falseness. We become aware of this through Milton's direct comments on Satan, through his description of Satan, and through the epic similes he employs. Often, of course the description of Satan can be taken at their face value. Also, such similes as those pertaining to his spear and shield are intended merely to produce a sense of size and wonder. But other descriptions and similes serve to build up an implicit sense of danger and menace which is to become explicit afterwards. For instance, there is the comparison of Satan with a sea-monster when he is "prone on the flood" (I. 200-2008). In this comparison, size is the dominant impression. But once the impression of hugeness has been created, the simile extends itself into the picturesque story of the small skiff and the sailor's delight at finding shelter on a darkened sea. The story here is one of deception. The reader experiences the same feeling as the benighted sailor must have experienced, namely, a feeling of having been deceived. The sailor was not safe but only thought that he was. Similarly, Milton means to say, man is deceived into a sense of security and then ruined by sin. Nicolson (1963) has commented on this point, saying that "the epic simile of Leviathan is a miniature version of Eve's experience in sinning" (37).

Critics have often refused to pay attention to Milton's plain words about the character and conduct and moral situation of Satan. They have often preferred to concentrate on Satan's heroic and romantic aspects, thus missing the truth of Milton's portraiture of the Devil. Satan is the enemy of God and man. That is his role in the story, and he must be equal to his role as the adversary of the Almighty. He must be shown as possessing the virtues and the powers which are necessary for him to play his part as the Arch-fiend. He must be shown as a towering genius. But we must never be allowed to forget that his genius is devilish. All his virtues are in fact corrupted by his situation and by the uses to which he puts his powers.

The original $\sin$ of Satan is the same as man'sdisobedience to God. The motive from which he acted was pride. Many think that Satan's pride is a reflection of Milton's own, that Milton unconsciously sympathizes with him, and that Satan therefore is the real hero of the epic. But this is a mistaken approach. Satan's pride makes him claim equality with God. It is this excessive sense of his own importance that governs all his conduct, and it makes him irretrievably evil. This fact (namely, that Satan is evil) determines his whole situation, his actions, and his words at every stage. He is incapable of repentance. He is a lost soul to "whom hope never comes that comes to all." This fact is summed up at the end of Satan's opening soliloquy in Book IV: "Evil be thou my good." It is a human instinct to admire the courage of despair and chivalrous devotion to a lost cause. Such courage Satan has, and such chivalry he does possess, and these have always aroused the admiration of readers. To simple-minded moderns, unversed in theological speculations, this admiration seems only right and proper. But Milton knew and repeatedly tells us that all Satan's words and deeds were perverse and vain. Many insist on regarding Satan as a Byronic hero, or give him all the credit for courage and endurance and leadership which they give to all worthy epic heroes. If we are to understand Milton's Satan, we must stop regarding him as a great unfortunate. This of course he is, like Macbeth, but like Macbeth he is wicked and unrepentant to the end. This makes him a great tragic figure but not an epic hero. To regard him as the hero of Milton's epic is to stultify the poet's whole intention.

Is Satan the hero of Paradise Lost? We might think so had we not read beyond the first book. But to trace his story in the poem to its inglorious close is to dispel the impression. Milton can scarcely intend that we should regard him as 'hero'-as worthy of sustained admiration-one who passes from the splendor of archangelic being to the state of loathsome reptile. Because Satan's character is round, it changes significantly from Book I though Book X, in which he makes his final appearance as a miserable creature, suffering from hell, but unable to repent. In Book I he is courageous and heroic with so many grand qualities, but as we see him in Book X, a complete degeneration has taken place in his character, which is illustrated by the different shapes he takes; from a determined hero into a cursed serpent. (www.sparkenotes.com).The hideous metamorphosis in Book 
$\mathrm{X}$ (504-532) is the necessary contrast to those scenes at the beginning of the epic in which the great rebel does appear in heroic grandeur: and we must look on both pictures. If Paradise Lost narrates the fall of man, it narrates too-and no less clearly-the fall of man's temper. The self-degradation of Satan is complete: outward and inward: of the form and of the spirit: a change-ever for the worse-of shape and mind and emotion.

There is the outward sign. Before his expulsion he is preeminently a lustrous being, clothed with ethereal radiance and glory. And afterwards he retains something of this original brightness: howbeit much has passed from him. But gradually what was left decreases in proportion as the evil in him prevails: so that Uriel perceives the foul passions that dim his face (IV. 124-130); while Gabriel marks his "faded splendor wan" (IV. 870). And the Cherub Zephon taunts him therewith (IV. 835-840). Equal is his loss of physical force. On the fields of Heaven he does not fear to meet Michael in combat (VI. 246-260); in the Garden of Eden he doubts himself a match for Adam. In fact he is glad that he has to deal with the woman, not the man (IX. 480-488).

Nor is this because of lost strength alone. He shuns the "higher intellect" of Adam (IX. 483), who would be better able than Eve to see through his arguments and so resist temptation. He is conscious of his own decline in intellect. The strong intelligence which inspires his speeches in the first two books has degenerated, by perverse use, into mere sophistical slyness, a base cunning. He is no more the mighty-minded archangel: he is naught but the serpent"subtlest beast of all the field" (IX. 86) Lastly, every impulse in him towards good has died out. The element of nobility that redeemed his character at the outset from absolute baseness has been killed. In evil he moves and has his being so that he confesses "all food to me becomes bane"; and in destroying lies his sole delight (IX. 118-119).

\section{Conclusion}

In conclusion, we, therefore agree that there has been any conflict here, as is often alleged, between Milton's intention and the result. Satan is not only a rebel but a tyrant. His words show how far he is from understanding true liberty. He has heroic qualities, as we have already seen. He is brave, strong, generous, loyal, prudent, temperate, and selfsacrificing. But if he has heroic virtues, so has Macbeth; and Macbeth is a villain. The reason why Milton has endowed Satan with these qualities is that an adversary to God had to be of massive dramatic stature and that the power that was to seduce Eve must have an impressive personality and character. The misinterpretation arises from the tendency in human nature to romanticize the rebel and the fighter against odds. Satan's heroism is false heroism because it is based on false beliefs and unworthy aims. False heroism has its dramatic side, and a certain interest. There is no doubt that Milton has used his poetic and dramatic powers to the full in portraying Satan. But that was natural. Milton felt inspired by Satan, and it is always much easier to create evil characters than ideally good ones. Hardly therefore shall we believe that Milton meant us to see in the fallen and ever falling archangel the hero of Paradise Lost. That position surely belongs to Adam.

\section{References}

[1] Banisalamah, Ahmed, M. F. "Milton's anti-monarchical stances and his poetical, phonetic, rhetorical, and theological crafts." Canadian Social Science, 11 (1), 2015, pp. 30-34. Retrieved from http://www.cscanada.net/index.php/css/article/view/5466

[2] Gordon, Teskey. (2005). Blake's The Marriage of Heaven and Hell. Paradise Lost. New York: Norton, 2005, p. 389.

[3] Shelley, Percy, B. A Defence of Poetry. Romanticism: An Anthology, ed. Duncan Wu. Oxford: Blackwell Publishers, 1998, pp. 944-956.

[4] Hazlitt, William. On Shakespeare and Milton, from Lectures on the English Poet, 1818.

[5] Fenton, Mary, C. "Hope, land ownership, and Milton's 'Paradise within'." Studies in English Literature, 1500-1900, Vol.43.1, 2003. Retrieved from http://go.galegroup.com/ps/i.do? Gale Document Number: GALE|A98312882

[6] Slotkin, Joel. "Poetic justice: Divine punishment and Augustinian Chiaroscuro in Paradise Lost." Milton Quarterly. Vol. 38. 2 (2004), 100-27. Retrieved from http://go.galegroup.com/ps/i.do? http://dx.doi.org/10.3968/5466

[7] Milton, John. Paradise Lost: A Poem in Twelve Books, ed. Thomas Newton. Oxford: Oxford University Press, 1749.

[8] Prince, Frank, T. 1912-Paradise lost. Books I and II. Oxford: Oxford University Press, 1962.

[9] Williamson, George. Milton \& Others. London: Faber \& Faber, 1965.

[10] King, John, N. Milton and Religious Controversy: Satire and Polemic in Paradise Lost. Cambridge: Cambridge University Press, 2000.

[11] Murray, Patrick. Milton: The Modern Phase. New Jersey: Prentice Hall, Press, January, 1967.

[12] Anderson, Jarod, K. The decentralization of morality in Paradise Lost. Ohio University: Rocky Mountain Review, 2010, pp. 198-204.

[13] Fuller, Edmund. John Milton. NY: Harper \& Brothers, 1944.

[14] Rudrum, Alan. A Critical Commentary on Milton's Paradise Lost. London: Melbourn (etc.) Macmillan, 1966.

[15] Broadbent, John. Paradise Lost: Introduction. Cambridge: Cambridge University Press, 1972.

[16] Shawcross, John, T. Milton, 1732-1801; the critical heritage. London, Boston: Routledge and K. Paul, 1972.

[17] Daiches, David. A Critical History of English Literature: Shakespeare to Milton. Tamil Nadu, India: Allied Publishers, 1976. 
[18] Tillyard, Eutace, M. W. The Miltonic Setting: Past \& Present. London: Chatto \& Windus, 1938.

[19] Lewis, Clive, S. A Preface to Paradise Lost. Delhi, India: Atlantic Publishers \& Dist, 2005.

[20] Forsyth, Neil. The Satanic Epic. Princeton and Oxford: Princeton University Press, 2003, p. 303.
[21] Nicolson, Marjorie, H. A Reader's Guide to John Milton. NY: Syracuse University Press, 1963.

[22] SparkNotes Editors. "SparkNote on Paradise Lost." SparkNotes.com. SparkNotes LLC, 2003. Retrieved from http://www.sparknotes.com.n.p. 